
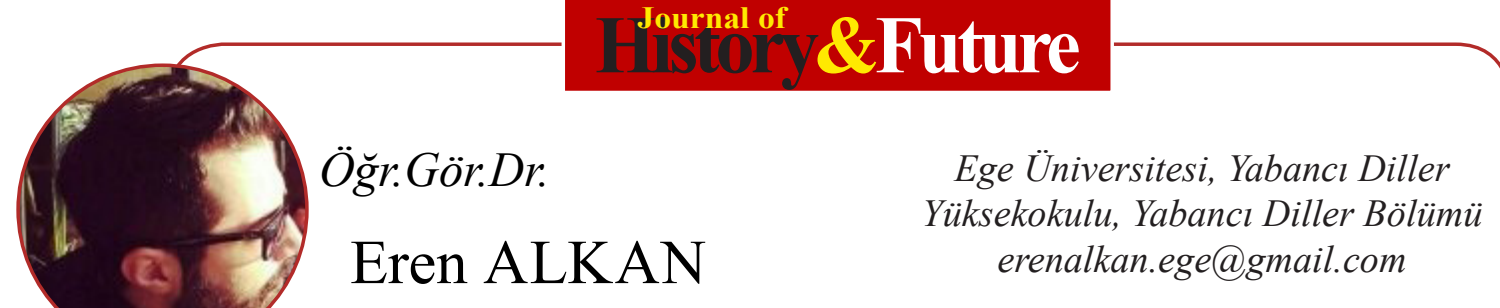

ORCiD: https://orcid.org/0000-0002-6447-9394

Eser Geçmişi / Article Past: 11 Tem 2019/ 5 Ağu 2019

Araştırma Makalesi

DOI: http://dx.doi.org/10.21551/jhf.590920

Research Paper

Orjinal Makale / Orginal Paper

\title{
Amerikan Sahnesinin Suflörü: Amerikan Tiyatro Tarihinde Şiddetin Yansimaları
}

\author{
Prompter of American Stage: The Reflections of Violence in
} History of American Theatre

\section{$\ddot{\mathbf{O} z}$}

Varlığıyla insana dair, doğuştan ya da sonradan edinilmiş bir dürtü anlamında olan şiddet, tiyatronun her zaman doğrudan ya da dolaylı olarak ana malzemelerinden birisi olmuştur. Tiyatro tüm zamanlarda bireyin üzerinde oluşan baskıları göz önünde bulundurarak ya da bireyin bu baskılarla mücadelesini, zaferini ya da kaybını anlatarak, bizzat şiddeti eleştirmiştir. Şiddet temasının özellikle Amerikan sisteminin devamını sağlayan kilit unsurlardan biri olması ve bireyin yaşadığı bunalımlarla doğrudan ilintili olması, onun Amerikan tiyatrosunun içeriğinde önemli bir yer tutmasını kaçınılmaz kılmıştır. Şiddet olgusunu ister istemez merkezine alan Amerikan tiyatro geleneği, birey üzerinde, şiddetin sonucu olarak kamusal düzlemde açığa çıkan toplumsal yabancılaşma, ötekileşme, hiçlik duygusu ve duygusuzlaşma gibi etkileri sahneye taşıyarak toplum ve birey arasında varlığı şart olan hayati köprünün güncel yıkımını gözler önüne serer. Bu incelemede Amerikan tiyatro tarihinin, şiddet olgusunun Amerikan kültürüne iktidar bağlamında sistematik bir şekilde nasıl yön verdiği, bireyi olumsuzluğa ve karamsarlığa ne yönde sürüklediği, merkezden marjine nasıl ötelediği, bireyin karar mekanizmalarını bizzat şiddetin kendisinin oluşturduğu betimsel olarak tartışılacaktır.

Anahtar Kelimeler: Amerikan tiyatrosu, Şiddet, Amerikan tarihi 


\begin{abstract}
Violence which means an acquired drive by birth or late has always been one of the main tools of theatre directly or indirectly. Theatre has taken suppression on individuals into consideration throughout the history or criticized that violence by telling about the victory, defeat, or struggle of individual with this suppression. It has caused to be unavoidable that the theme of violence is one of the key actors that especially provides the continuity of American system and is directly related to individuals' nausea so that it is an important part of American theatre. Tradition of American theatre which focuses on violence necessarily, makes it clear that social alienation, otherization, sense of nada, and indurations which emerge on public sphere as the result of violence are staged to show how the vital bridge between society and individual collapses. At that point it is so crucial that history of American theatre reflects how violence directs American culture systematically in terms of power relations, takes individual into pessimism, marginalizes, helps her/his decision making processes be formed by violence's itself by using both a clear and a tough language.
\end{abstract}

Keywords: American theatre, Violence, American history

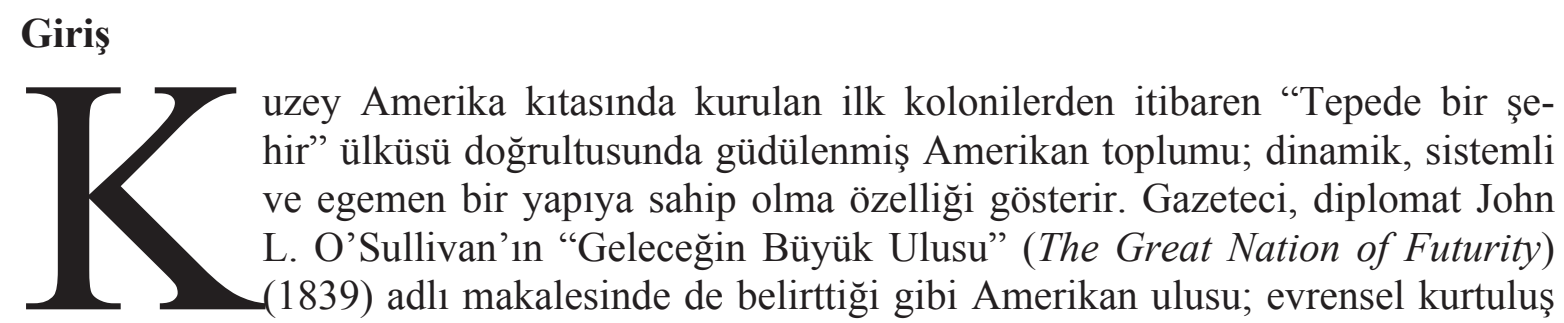
ve özgürlüğü ancak ve ancak dünya lideri olursa kazanabilecektir; çünkü eski Avrupa sistemi, O’Sullivan’a göre, yozlaşmıştır. Yeni bir kıtada on yedinci yüzyılda yaratılmaya başlanan sistemin, yirminci yüzyılın küresel ortamında egemenliğini esas kılmak için başvurması gereken en önemli araçlardan birisi de, bu noktada, hiç kuşkusuz "şiddet" olacaktır. Bu şiddeti de sosyolog Josiah Strong, "Ülkemizin Olası Geleceği ve Şu Anki Krizi" (Our Country: Its Possible Future and Its Present Crisis) $(1885)^{1}$ isimli makalesinde belirttiği üzere, O'Sullivan'ın çalışmasını da ilerleterek, "zayıf uluslara" kendi kültürlerini bir şekilde dayatarak uygulatmayı savunur. Böylece tüm bir toplumu içine alacak şekilde kamusal şiddete önemli bir misyon yüklenir; bir başka deyişle hem politik olarak hem de kültürel olarak Amerikan sistemini kalıcı kılma, yayma hatta dogmatikleştirme konusunda şiddet, baskıcı güçlerden biri konumuna getirilir. Amerikan sisteminin ataerkil uygulayıcıları -politikacılar, medya patronları, sanatçılar, din adamları, kimi zaman filozoflar, toplum bilimciler ve dil bilimciler- kamusal şiddet politikalarını topluma öyle empoze ederler ki şiddetin salt varlığı; halk tarafından, insanın -hatta toplum ve evrenin- özünü oluşturan bir yapı taşıymış gibi algılanır. Örneğin, Morris Birkbeck, Timothy Dwight, Peter Cartwright ve Frederick Jackson Turner gibi Amerikalı yazar ve araştırmacılar, baskın kültürün ve bu kültürün açılımlarının önemli ölçüde yerine oturtulmasını ve bunun teorik ve pratik nedenleri ile ilkelerini özellikle Batı'ya açılma örneğiyle dile getirirler. Buna karşı çıkan görüşler ise (özellikle on dokuzuncu yüzyılın sonu, yirminci yüzyılın başında Bret Harte'ın "The Outcasts of Poker Flat" [1869], William Dean Howells'in Criticism and Fiction [1891], Henry James'in “The Real Thing” [1893], Stephen Crane'in "The Open Boat" [1898], Edward Arlington Robinson'ın "Miniver Cheevy" [1910] ve "Mr. Flood's Party" [1921] adlı eserleri; gerçekçi akımın izinden kapitalizm ve sistem

1 Josiah Strong, Our Country: Its Possible Future and Its Present Crisis (USA: The Classics 
kurbanları, insan doğası ve çevresel koşulların uyguladığı baskı ve şiddet, toplumsal gücün bireyin özgürlüğünü baskılayıp parçalaması temalarını işlemesi bağlamında güçlü örnekler olarak işaret edilebilirler) Amerikan tarihinin hiçbir safhasında kamuoyunun tamamını etkileyememişler; daha akademik düzeylerde ve görece küçük gruplarda yankı bulmuşlardır. Nitekim sistem güçlendikçe ve ileri kuşaklara aktarıldıkça gelişen kültürel yapı, şiddetin denetiminde baskın folkloru oluşturur. Uyguladığı şiddeti; dinsel haklı çıkarımlar, teknoloji, medya, popüler kültür ve kapitalizm ile süsleyen Amerikan sistemi modern dünyada tüm bu bilgi birikimi ve donanımı sayesinde daha çok geçici unsurlarıyla ön plana çıkmış olsa da kullanılan şiddet genellikle yüzeyde görünmeyen yaptırımlarıyla birey üzerinde her daim ezici varlığını hissettirmiştir. Ancak; hem şiddeti uygulayan hem de şiddetin uygulandığ 1 birey, şiddetin sistemi cisimleştirip yapıya zarar verilmesini imkânsız kıldığını bilerek umutsuz bir kabul edişle şiddeti uygulamaya/ona karşı tavır almaktan korkmaya devam etme döngüsü içinde sıkışmıştır. Bu noktada şiddetin Amerikan siyasi, ekonomik ve kültürel tarihinin devamını sağlayan en önemli unsurlardan biri olduğu gerçeği, özellikle yirminci yüzyıl modern Amerikan bireyinin içerisinde yaşadığı bunalım bakımından dikkat çekicidir. Sistemin içinde soğurulan şiddet, birey üzerinde yabancılaşma, ötekileşme, hiçlik duygusu ve duygusuzlaşma gibi etkilerin doğmasına neden olurken kültür ve birey arasında varlığı şart olan hayati köprüyü de zamanla yıkmaya başlar. Popüler kültür, muhafazakâr yapı, medya ve tüketim ile şiddetin somutlaştığg ordu gücünü de yanına alan sistemin, Amerikan bireyinin zihninde kültürle ilgili büyük bir kaos yarattığı da tartışılmaz bir gerçektir.

Bu bağlamda Amerikan edebiyatının tüm dallarında da şiddet olgusunun, Amerikan kültürünü nasıl oluşturduğu ve ona sistematik bir şekil verdiği ve bu kültürün de Amerikan bireyini ne ölçüde, hangi koşullarda etkilediği, onu nereye ötelediği ve onun üzerinde nasıl bir yaptırımı olduğu ile ilgili yansımaları görmek ve özellikle modern dönemde oldukça sert bir şekilde vurgulanmış olduğunu tespit etmek mümkündür. Birinci Dünya Savaşı öncesinde kölelik, (Harriet Beecher Stowe'un Tom Amca'nın Kulübesi [1852] romanında örneklendiği gibi), İç Savaş (Margaret Mitchell'in Rüzgâr Gibi Geçti [1936] romanında betimlendiği gibi) ya da yüksek sosyete (Edith Wharton'ın Masumiyet Çăgı [1920] romanında yansıtıldı̆̆ı gibi) konuları bağlamında, Amerikan eserlerinde kamusal şiddetin birey üzerindeki etkisi; sırasıyla köle ticaretinde beyazların siyahlar üzerindeki şiddeti, savaşın birey üzerindeki toplumsal baskısı ve yıkıcılığı ve toplumsal normların ve kültürel dokunun birey üzerindeki psikolojik yaptırımı üzerinden edebiyata pek çok yazar tarafindan dâhil edilmiştir. Savaş sonrası dönemde ise yazarlar zaten varlığ yok edici olan şiddetin özünü, onu bir şekilde görmezden gelmeye çalışarak, umutları kırık, "kaybolmuş" ve hiçlik duygusuna batmış bir şekilde alırlar eserlerine. "Kayıp Kuşak" (Lost Generation) ve "Harlem Rönesansı" gibi kimi gruplar içerisinde benzer temaları işleyerek gerçekliğin şiddetle, somut bir şekilde de savaş ile bölünmüşlügünü anlatırlar -Ernest Hemingway'in romanları, Gertrude Stein'ın hikâyeleri, William Faulkner'ın roman tekniği, Langston Hughes ve Countee Cullen'ın şiirlerinde görüldüğü gibi.

Kamusal şiddetin birey üzerindeki kültürel ve sosyal etkilerinin izlencesi ise daha somut bir ayna tutması bağlamında belki de en net ve dolaysız olarak Amerikan tiyatrosunun gelişiminde takip edilebilir. Romanlarda yer alan uzun tasvirler ile yoğun ve uzun sembolik dil kullanımı ya da şiirlerde yer alan kimi zaman anlaşılması güç söz sanatları veya özellikle bilinç akışı tekniği kullanılarak yazılan hikâyelerde yer alan kısa ama çok yönlü alegorik ve sembolik parçalanmış dil kullanımı gibi dolaylı anlatımlarıyla karşılaştırıldığında görsel bir seyir sunan tiyatro, bu üç türe göre mesajın doğrudan aktarımını sağlayarak daha fazla ön plana çıkarmıştır. Hem oyunda kullanılan sahne direktifleri, dekor, karakterler, makyaj, ses ve müzik gibi tiyatroyu oluşturan ana metin dışındaki unsurlar seyircinin olayı özümsemesine yardımcı olur hem de görsel olarak şiddetin yansıtılışını herhangi bir hayalî zorlamaya gerek kalmaksızın gözler önüne serer. Kişiye değil 
de kitleye hitap ettiği için de dili genelde diğerlerine göre daha kolay ve daha az akademik/entelektüeldir. Bu bağlamda şiddetin birey üzerindeki etkisi, aynı mekânın (tiyatro salonu), metindeki karakterler ve seyirci tarafından paylaşılmasının verdiği itkiyle daha da gerçekçi bir boyut kazanır. Tiyatro alanında toplu bir seyir, dolayısıyla toplu bir algılayış vardır yazılı kurguların aksine. Bu da yazar tarafından verilmek istenen mesajın daha hızlı ve geniş çapta aktarımını sağlar. Ayrıca toplu bir paylaşımın edinimine de yarar. Şiddetin birey üzerinde uygulanması sebebiyle somutlaşması (sahne üzerinde oyuncular jest, mimik ve dil ile bunu somutlaştırırlar), somut bir zeminde yapılan tiyatronun bu uygulamayı diğerlerine göre daha açık bir şekilde yaptığı sonucunu verir. Yukarıda da belirtildiği gibi tiyatronun yardımcıları çoktur (dekor, sahne, oyuncular, müzik gibi); ancak diğer edebi türler sadece kelimeleri (kimi zaman şekilleri) kullanır. Bu noktalar göz önünde bulundurulduğunda, şiddetin modern Amerikan bireyi üzerindeki etkisinin tiyatro ile daha iyi yansıtılabileceği sonucuna varırız. Sonuç olarak, yukarıda da belirtildiği üzere, kamusal şiddetin modern Amerikan bireyi üzerindeki baskısı ve bu baskının etkileri Amerikan tiyatro tarihinin de önemli izleklerinden birisini oluşturur.

Özetle, tiyatro sahnesinde de sık sık dolaşıma sokulduğu üzere, şiddete giden tüm kültürel yollar tek bir temel gerçeğe işaret eder. İnsanlar korku, travma ya da karşılanmamış ihtiyaçlarla yüz yüze geldiklerinde şiddete başvururlar. Şiddeti bunlarla başa çıkmanın bir yolu olarak görürler. Daha uç noktasında şiddetin adalet ve özgürlük için meşrulaştırılması, ordu ve asker kullanımı, polisin şehir içerisindeki gücü bunun önemli bir göstergesidir. Kısaca, şiddet davranışları bilişsel ya da duygusal süreçler yoluyla toplumsallaştırılır ve bunlar, toplum içerisinde yaşayan birey üzerinde kamusal şiddetin baskı unsurları hâline gelir. Bu bilgiler 1şı̆̆ında on dokuzuncu yüzyıl sonu ve yirminci yüzyılın ilk yarısında Amerikan tarihi ve tiyatro geleneğinde şiddetin yeri incelenecektir.

\section{On Dokuzuncu Yüzyıl Sonu ve Yirminci Yüzyılın İlk Yarısında Birleşik Devletler’de Kamusal Şiddetin İzdüşümleri}

Thomas Edison ile beraber elektrik endüstrisinin doğumunun gerçekleşmesi ve Henry Ford ile de 1890'larda otomobilde kitlesel üretimin başlaması Amerikan ekonomisine on dokuzuncu yüzyılda yön veren temel etkenlerden ikisidir. Montaj hattını uygulayanlar, bir yandan endüstriyel devrimi sistematik bir hâle getirip ardından da bunun zaferini ilan ederlerken bir yandan da kapitalizmin dişlilerini bireylerin özgürlüklerine ve aidiyet duygularına geçirmesinde önemli bir rol oynarlar. Yeni makinelerin icadı ve sağladığı avantajlar büyük fabrikaların kapasitelerini büyütmelerini sağlar; bununla birlikte yerel ve küçük işletme ve fabrikaları yok ederek tekelleşmenin öncülügüüü yapar. Yeni pazar tekniklerinin geliştirilmesi ve makineleşme, işçi sayısına olan talebi azaltarak işverenlerin işçiye olan bağlılığını da zedeler; bu durum sendikaların ve işçi haklarının yıpranmasına da neden olarak kamusal şiddetin ağırlık mekanizmasını genişletir. Üretimin artması, daha fazla satışın yapılmasını zorunlu kılar; daha fazla satış yapmak için de fiyatların azaltılması gerekir. Daha fazla kazanç sağlamak içinse üretimin daha fazla genişlemesi ve sık sık ücretlerin azalması lazımdır. Bu noktada genişleme yapabilmek için paraya ihtiyaç vardır. Parayı ödemek içinse daha fazla üretim ve satışa. Bu süreç, küçük sermayeli şirketlerin tamamen yıpranmasına yol açar. Tüm bu tüzel birlik hareketi kartellerin, tröstlerin ve dikey bütünleştirmeyi teşvik eden holding şirketlerinin kurulmasıyla sonuçlanır. Böylece sistem, rekabeti ortadan kaldırarak ham maddeden nakliyeye, imalattan fabrikasyona kadar her şeyi tekelinde bulunduracaktır. Kısaca, Herbert Spencer'in Sosyal Darwinizm olgusuyla öngörülmüş olan ve Adam Smith'in de belirttiği şekilde "Bırakınız yapsınlar, bırakınız geçsinler" ifadesiyle simgeleşen kapital tekel güç, kamusal şiddetin dönemin çağdaş bireyi üzerindeki en büyük göstergesidir. On dokuzuncu yüzyılın sonlarına doğru endüstriyel ve ticari anlamda en hırslı dönemlerinden ilkini yaşayan Amerikan kapitalizminin 
uyguladığı şiddet, 1877 demiryolu işçileri grevleri, Haymarket İsyanı ve Pullman Grevi ile durdurulmaya; Henry George'a göre, "ütopik ekonomik şemalarla yok edilmeye"2 ya da 1890 Sherman Anti-Tröst Yasası gibi tröst karşıtı düzenlemelerle hafifletilmeye çalışılsa da kadın işçiler, etnik kökeni farklı çalışanlar ve çocuk işçi kullanımı ile endüstriyel kazalar da dâhil olmak üzere bu güç özellikle proletarya üzerinde farklı boyutlarda ama tüm yoğunluyla bireyleri daha çok sindirmek üzere artmaktadır. 1877-1920 Makine Çă̆l, sonuç olarak, şiddetin en teknik yılları olmuş ve kamusal alanda halkı kitlesel olarak güçsüzleştirerek onlara edilgin ve mekanik yaşamlar armağan etmiştir. Kentsel-endüstriyel gelişim, ulaşımı kolaylaştırmış ki bu da göç sorununa ve bu sorun da şehir planlamalarının sakat bir şekilde gelişmesine yol açmıştır. Tüketim toplumu bilinciyle değişime uğrayan göçmen gruplar kendi kültürleriyle değişimin yarattığı yeni toplumsal normları harmanlayarak hibrit kimlikler kazanmışlardır. Toplumsal şiddet, özellikle ekonomik olarak alt sınıfı oluşturan insanların kimliklerinin içlerini boşaltarak onları marjinalleştirmiş ve ötekileştirmiştir. Ev problemleri, yoksulluk ve epidemik hastalıklar da durumu kötüleştirerek suç ve şiddetin bireyler arasında yayılmasına neden olmuştur.

Birleşik Devletler'de yirminci yüzyıla gelindiğinde büyük oranda kapkaç, adam kaçırma, hırsızlık ve türevi suçlar oldukça yoğun bir şekilde görülmektedir. ${ }^{3}$ Isssizlik ve ücret sorunları, Avrupa ve Asya kökenli göç sorunlarıyla birleşince çekişme de artar; bu, özellikle kendilerini Amerika'nın yerlisi sayanların Amerikalı olmayan gruplara toleransını da azaltır. Etnik gruplar arasında yaşanan çekişme ve şiddet (Wilmington, 1898; Atlanta, 1906; Springfield, 1908 olaylarında görüldüğü gibi) devletin birey üzerindeki baskısının daha fazla hissedilmesine, polisin fiziki şiddet kullanma yetkisinin daha çok artmasına neden olmuştur. Bunun sonucunda ortaya çıkan banliyöler ise ötekileşen grupların arasında görünmeyen çizgilerin belirmesine ve şiddetin daha sert noktalarından kırılmasına yol açmıştır. Birey, üzerindeki kamusal şiddeti, politik bir söylem olan boş zaman kavramı içinde sporla ilgilenerek, sirke giderek, popüler drama ve müzikal komedi izleyerek, vodvil eğlencelerine katılarak, film seyrederek, sarl gazetecilikle medya tarafindan yönlendirilerek, ucuz romanlar okuyarak ve ahlaki açıdan muhafazakâr masallar dinleyerek; kısaca beyinlerini uyuşturarak unutmaya çalışır. Amerikan düşün ve yazın dünyası da "yaldızlı dönemin" (Gilded Age) buhranlı atmosferi içinden (1890 depresyonu ve bankaların batması) Büyük Buhran'a uzanan sosyoekonomik çalkantıların fonunda filizlenip şekil alacaktır.

Robert Marion La Folette gibi valilerce desteklenen ilerlemeci hareket savunucuları ise tüm bu kamusal şiddeti azaltmak adına savaşım vermektedirler. Kadın kuruluşları, etnik dernekler ve işçi grupları yaşam standartlarını daha iyi hâle getirmek için eğitim, hukuk ve sosyal bilimler alanlarında yeni kolej ve üniversitelerden de destek alırken, gelenekçi gruplar ahlaki reformlarla içki, fuhuş ve suç bağlamında şiddetin daha muhafazakâr yöntemlerle azaltılmasını planlarlar. Birey üzerinde artan sosyoekonomik bask1, ilerlemeci hareket doğrultusunda Booker T. Washington ve W. E. B. Du Bois gibi aydınların demeçleri ışığında Afro-Amerikalı azınlık üzerinden dile getirilirken, kadın kulüpleri ve feminist hareket de kadına uygulanan şiddeti azaltmaya yönelik çalışır. Ancak şiddete karşı çıkış çabaları, dışarıda yayılmacı ve emperyal hareket (Hawaii, Venezuela, Küba, Filipinler ve Panama vakaları), içeride tekelcilik, kapitalizm ve büyük şirketlerin krallığı ile yaklaşmakta olan Birinci Dünya Savaşı arasında kalarak kürtaja maruz kalacaktır. Birinci Dünya Savaşı ise açlık, sefalet ve siyanür gazıyla taburlar hâlinde yok edilen askerler ile şekil alan ve fiziksel bağlamda şiddetin ayyuka çıktığı sahnelere neden olacaktır. Bu savaş ayrıca eve dönüş,

2 Wadsworth Publishing, A People \& A Nation (United States: Wadsworth Publishing, 2014), 16.

3 Wadsworth Publishing, A People \& A Nation (United States: Wadsworth Publishing, 2014), 28. 
hayal kırıklıkları, yabancılaşma, devlet gücüne karşı güvenin yok olması, bilinç karmaşası gibi sonuçlara neden olacak; bunun devamında ise bireyin hayatında gerçeklikten kopuş, bulantı (nausea) ve hiçlik (nada) gibi hislerin oluşmasına yol açacaktır. Böylece bireyde kendini gösteren ruhsal şiddetin yaşama yön vermesi Amerikan toplumunu, tüm dünyada olduğu gibi yıkıcı bir şekilde sarsar. Tüketim toplumu yapısı, kapitalizmin üst seviyelerdeki etkisi ve yeni idealizm, halkı bir fanusun içine iterek gerçeklikten koparır. Diversifikasyon (ürün çeşitlendirme politikası) yoksunluğu, satın alma gücünün kötü dağılımı, ekonomideki kredi yapılanması, Amerika'nın uluslararası ticaretteki durumu, fazla üretim, Birinci Dünya Savaşı'ndan kalan ve alınacak olan uluslararası borç, banka endüstrisi, eksik tüketim ve yoğun stok pazar spekülasyonu gibi nedenlerle ortaya çıkan ve tüm dünyayı tesiri altında bırakan Büyük Buhran ise yoğun şiddetiyle en ön planda olan kamusal yaptırımdır. 1933-1939 yılları arasında çıkan Roosevelt' in Yeniden Yapılanma programları sonrasında gelen İkinci Dünya Savaşı ve Soğuk Savaş dönemleri (bu savaşlarla Amerikan politikası ve ekonomisi tüm dünyada egemenliğini ilan ederken, birey hıllı tüketim, medya ve popüler kültürün de etkisiyle postmodernizmin içerisine yuvarlanarak hiçliğin içine hapsolur) ise depresyonla başlayan fonun yıkımla bitmesiyle son bulur.

Kısaca, ABD’de tanık olduğumuz özellikle kapitalist anlayışın beslendiği ve körüklendiği şiddet, sadece azınlığı oluşturan zengin üst sınıf haricinde, bireylerin hayatlarını şekillendiren, anlamlandıran, tanımlayan, genetikleştirip kimliklerini oluşturan bir öz yasa ya da varlığı belirgin bir hayalet olarak tüm insanların kişisel tarihlerinin ardılı, aynası ve gölgesi olur.

\section{Amerikan Tiyatro Geleneğinde Kamusal Şiddet Sufleleri}

Birleşik Devletler'de kamusal şiddetin yukarıda bahsedilen iz düşümleri kapsamında Amerikan tiyatro geleneğinde nasıl bir etkisi olduğu daha rahat irdelenebilir. 1812 Savaşı'nı takip eden yıllarda Amerika'nın doğu eyaletlerinden batıya doğru yapılan göçün hız kazanması ve 1850'lere gelindiğinde Amerika Birleşik Devletleri'nin üç katına kadar genişlemesi, bu yeni topraklara yerleşen insanlarla birlikte tiyatro faaliyetlerinin de kültürel arenada yeniden boy göstermeye başlamasına yardımcı olmuştur. Profesyonel anlamda tiyatro faaliyetleri ise 1791 yılında New Orleans’ta görülmeye başlanmıştır.

Samuel Drake kurduğu bir tiyatro topluluğunu 1815 yılında ülkenin dört bir yanını kapsayan bir turneye çıkartınca, "Batı"da da profesyonel tiyatro yapılmaya başlanmıştır. Zamanla Drake'in rakipleri ortaya çıkmaya başlamıştır ki bunlardan en önemlisi 1816'da Amerika'ya gelen İngiliz komedya oyuncusu James H. Caldwell'dir. Oyunculuğuyla adından sıkça söz ettiren ve önemli miktarda maddi güç kazanan Caldwell, 1837 bunalımında kazandığı maddi gücü ciddi ölçüde kaybetmiştir ve 1843 yılında tiyatroyla ilişkisini kestiğinde onun boş bıraktığı rakip koltuğunu Ludlow ve Smith almıştır. Bu ikili 1840 yılına kadar Gezgin Tiyatro'yu idare etmişlerdir ve 1843-1853 yılları arasında Caldwell' in tahtına oturmuşlardır. Yalnız oyunculuklarıyla değil, yönetmen kişilikleriyle de ön plana çıkan ikilinin tiyatral deneyimlerini yazıya dökerek Amerika'nın yeni göç edilen yerlerde oynanan oyunları kapsayan "sınır" tiyatroları konusunda en önemli bilgi kaynaklarını da oluşturdukları kabul edilmektedir. ${ }^{4}$

Batı şeridinde yerleşim faaliyetleri sürerken doğudaki şehirlerde de nüfus artışı gözlenmektedir. Örneğin, 1800 yılında nüfusu 60.000 olan New York, 1840 yılında 312.710 kişiye ev sahipliği yapmaktadır. Bu nüfus artışının sonucu olarak ortaya çıkan tiyatro eğlencesi talebinin sonucunda mevcut tiyatrolar genişletilmiş, haftalık gösterimlerin sayısı arttırılmış ve yeni tiyatro toplulukları

4 Oscar Brockett, Tiyatro Tarihi, haz., İnönü Bayramoğlu (Ankara: Dost Kitabevi Yay., 2000). 424-439. 
da kurulmaya başlanmıştır.

1800-1850 yılları arasında tiyatroların repertuvarlarında melodramlar öne çıkmaya başlamıştır ve kullanılan tiyatral efektler, ahlaki değerlere yapılan vurgu ve kurgulamalar gittikçe daha fazla sayıda tiyatroya gelmeye başlayan eğitimsiz seyirci topluluğuna yöneliktir. Bu oyunların pek çoğu, yapay bir şekilde mutlu sonla bitse de tiyatro artık; işçi hakları, kölelik, gecekondu yaşantısından temellenen şiddet gibi güncel konular hakkında da eleştirilerin yapılabildiği bir iletişim aracı ve platform olmaya başlamıştır. Özellikle Kızılderili, Amerikalı, Afro-Amerikalı ve şehir çocuğu gibi tiplemeler üzerinden sosyal şiddeti doğuran toplumsal meselelere vurgu yapılmaktadır.

1848'de Kaliforniya' da altın bulunmasıyla Batı'ya doğru yapılan göç hareketi, tiyatronun da gelişmesine zemin hazırlamıştır. 1869 yılında kıtayı boylu boyunca kat eden demiryolunun ulaşıma açılmasıyla, tiyatro önemli ölçüde güç kazanmıştır. Bu dönemin en çok sevilen, her oynandığında tiyatroya yüzlerce seyirci çeken oyunu, George L. Aiken'1n Harriet Beecher Stowe'un romanından uyarladığı Uncle Tom's Cabin'dir (1852). Ayrıca bu dönemde İngiltere'de olduğu gibi, burlesk ve extravaganza ${ }^{5}$ en popüler dramatik türlerdir. ${ }^{6} \mathrm{Bu}$ dönemde şiddetin yansitılış1 ise daha çok kölelik ve işçi hakları gibi güncel ve sosyal olaylar üzerinden eleştirel bir düzeyde yapılmaktadır.

1870'li yıllarda New York'un tiyatronun merkezi hâline gelmesi ve repertuvar sisteminin yerini uzun erimli oyunlara bırakmasıyla Amerikan tiyatrosunda büyük değişiklikler meydana gelmiştir. Bu dönemin oyunları gerçekçilik eğilimindedir ve bu eğilime rağmen birçok tiyatro popüler olanı sürdürmekte 1srar etmiş, yeni burlesk ve vodvil kavramlarını yaratmak üzere önemsiz dramatik biçimler, varyete gösterileri ${ }^{7}$ ile birleştirilmiştir ve bu bağlamda sahnede şiddetin yansıtılış biçimleri genellikle yüzeysel olarak kalmış, şiddet varlığını oyunların içeriklerinden çok oyuncuların yaşamları üzerinde daha fazla hissettirmeye başlamıştır.

1896 yılında kurulan "Birlik,", Amerikan Tiyatrosu üzerinde etkili bir denetim sağlarken 1915'le birlikte tiyatronun popülaritesi seyir sporları ve sinemayla girdiği rekabet sonucunda düşüşe geçmiştir. ${ }^{9}$

Büyük Buhran ile birlikte 1930'larda ülke, enerjisini büyük ölçüde ekonomik sorunları alt etmeye harcamıştır. Bu yılların en ünlü topluluğu, Moskova Sanat Tiyatrosu model alınarak kurulan Group Theatre'dır ve İşçi Tiyatrosu Birliği ile başlayan "işçi tiyatrosu” hareketine de büyük bir itki sağlamıştır; fakat buhran derinleştikçe oyun yazarları için özellikle sıra dışı yapıtları sahnelemek zorlaşmıştır. 1915 ile 1940 yılları arasında Amerikalı oyun yazarları gerçekçi üslubu melodramlarla romantize edilmesine şiddetle karşı çıkmışlar ve ülke dışında da popüler olmaya başlamışlardır. ${ }^{10}$

5 Ölçüsüzlük anlamına gelir. Bir müzikal tiyatro çeşidi olarak teknik ve içeriğinde yönetmen ve oyuncuya özgür bir ortam sağlar. Burlesk, pandomim, parodi gibi komedi türlerini de kimi zaman bünyesine katar.

6 Oscar Brockett, Tiyatro Tarihi, haz., İnönü Bayramoğlu (Ankara: Dost Kitabevi Yay., 2000). 461-471.

7 Tiyatro terimleri sözlüğüne göre "on dokuzuncu yüzyılın sonlarında Avrupa'da kabare tiyatrosu, müzikhol ve sirkin etkileriyle ortaya çıkmış dans, müzik ve akrobasiye dayanan" eğlenceye yönelik tiyatrodur. "Tiyatro Terimleri Sözlüğü,” son güncelleme 3 Ağustos, 2013.http://tiyatro-terimleri.bunedir.org/undefined?

8 Birlik (Theatral Syndicate) 1896'da New York'ta Charles Frohman, Al Hayman, Abe Erlanger, Samuel F. Nixon ve Fred Zimmerman tarafından oluşturulan ve genellikle İngilizcede sık sık The Trust diye bahsedilen Birleşik Devletler'de yüzlerce tiyatroda sistemli randevu ve kontrat ağı kuran bir tekeldir. Bu tekel, 191. 'larda Shubert ailesinin tiyatro endüstrisine girmesiyle kırılabilmiştir.

9 Oscar Brockett, Tiyatro Tarihi, haz., İnönü Bayramoğlu (Ankara: Dost Kitabevi Yay., 2000). 523-528.

10 Özellikle bu döneme oyunlarıyla damgasını vurmuş Eugene O'Neill oyunları izleyiciye dönemle ilgili etraflı bir şekilde bilgi verir. 
İkinci Dünya Savaşı, tıpkı ilki gibi, tiyatronun olağan gelişimini kesintiye uğratmışsa da, bu savaşın getirdikleri ayrıca Nazi toplama kampları ile atom bombası gibi yıkıcı silahları yaratan bir dünya hakkında da ciddi kuşkular uyanmasına neden olmuştur. Bu sorgulamalar da, tiyatroda ve oyun yazarlığında yeni denemelere girişilmesine neden olmuş ${ }^{11}$ ve şiddetin birey üzerindeki etkisini yansıtmaları için oldukça fazla konu sağlamıştır. Amerikan tiyatrosunda II. Dünya Savaşı sonrasının en etkileyici figürleri kuşkusuz, yönetmen Elia Kazan ve tasarımcı Jo Mielziner'dir. Bu ikilinin, Tennessee Williams'ın Arzu Tramvayı (1947) ve Arthur Miller'ın Satıcının Ölümü (1949) üzerine ortak çalışmaları, 1960'lara dek egemen olacak bir yapım anlayışını getirmiştir. 1947'de Robert Lewis, Elia Kazan ve Cheryl Crawford tarafından kurulan Actor's Studio seçilmiş oyuncuların Stanislavski yöntemine göre, çalışmaları ve kendilerini geliştirmelerine fırsat tanımak için tasarlanmıştır. Oyuncuların kullandıkları Avrupa menşeli yöntemler özellikle Williams ve Miller gibi yazarların eserlerinde işlenen konularla birleşince şiddetin toplumsal iz düşümleri izleyiciye daha iyi yansır. Cürümsel şiddet, karakterler üzerinden vücut bulduğu için izleyici sosyal hayatta yaşadığı şiddeti sahnede doğrudan görür.

Savaştan sonra televizyonun hızlı gelişimi, tiyatroyu ciddi bir biçimde tehdit etmiştir. $\mathrm{Bu}$ yeni araç tarafından sunulan parasız eğlence, tam da tiyatroda yapım giderlerinin hızla arttı̆̆ bir zamana denk gelmiştir. 1940'ların ikinci yarısında, Amerikan tiyatrosunun birkaç Broadway yapımına varacak derecede küçülmesi, tiyatronun tanımını değiştirecek kimi yaklaşımların ortaya çıkmasına hizmet etmiştir. Bu çabaların en önemlilerinden biri Off-Broadway ${ }^{12}$ hareketidir. 1960'larda Amerikan tiyatrosu Eugene O'Neill, Tennessee Williams ve Arthur Miller'ın oyunlarıyla ivme kazanırken, Edward Albee dönemin en prestijli isimlerinden birisi olmaya adaydır. Bu dönemde ise şiddetin sahneye yansitılışında Avrupa kökenli uyumsuz tiyatro ile Epik tiyatronun etkileri görülür. Şiddetin tematik olarak ele alınışında bu dönemin en büyük siyasal olayları olan İkinci Dünya Savaşı, Soğuk Savaş ve faşizm ön plandadır. Sonuç olarak, kamusal şiddetin etkisi ve kullanılış biçimleri her zaman Amerikan tiyatrosunu şekillendirici, ona yön verici bir olgu olmuş ve bir gölge gibi oyunların izleğini takip etmiştir. Kısacası, giriş bölümünde başından beri bahsedildiği gibi bu çalışmanın ana teması, özetle kamusal şiddetin, modern Amerikan bireyinin üzerindeki iz düşümlerinin modern Amerikan tiyatrosunda nasıl yankı bulduğu, yazarlar tarafindan nasıl işlendiği ve sahnede yansıtıldı ğı, bireye karşı uygulanan suçların ve cezalandırmaların sistematik bir şekilde şiddet olgusu üzerinden bireyi nasıl şekillendirdiği sorunsalları üzerinde yoğunlaşmaktadır.

11 Oscar Brockett, Tiyatro Tarihi, haz., İnönü Bayramoğlu (Ankara: Dost Kitabevi Yay., 2000). 559-569.

12 Wikipedia’ya göre, “New York’ta ancak Broadway Tiyatrosu tanımı dışında sergilenen oyun, müzis kal ve revüler (skeçler ve monologlardan oluşan eğlenceli gösterileridir.) için kullanılan kapsayıcı bir terimdir”. Off-Broadway 1960'lar boyunca da New York tiyatro yaşamına canlılık getirmeyi sürdürmüştür. Birçok Off-Broadway topluluğu içinde kuşkusuz en etkilisi 1946'da Judith Malina ve Julian Beck tarafından kurulan Living Theatre'dır. 1964'te Living Theatre Amerika'dan ayrıldığında, OffBroadway tiyatrosu da tıpkı Broadway’in yaşadığı ekonomik baskıya benzer bir sıkıntı yaşamaya başlar. Off-Broadway geriledikçe onun yerini "off-off-Broadway alır. New York'ta Broadway ve OffBroadway tiyatrolarından daha küçük sahnelerde gerçekleştirilen bu tür; tiyatro oyunu, müzikal ve performans prodüksiyonlarına verilen isimdir." Off-off-Broadway 100 koltuktan daha az kapasiteye sahip tiyatrolardan oluşur. "Broadway," son güncelleme 13 Haziran, 2019. https://tr.wikipedia.org/ $\underline{\text { wiki? curid }=1092779}$ 


\section{Sonuç}

Giriş bölümünde anlatıldığı üzere, şiddetin Amerikan kültürü üzerindeki etkisi onu şekillendirici ve ona yön vericidir. Ayrıca şiddet siyasi ve ekonomik söylemin anahtarı konumundadır. Dolayısıyla şiddet, Amerikan tiyatro geleneğinin de ana temalarından birisini oluşturmuştur; çünkü şiddetin, toplumsal yapılanmanın oluşturulmasındaki etkisi çözümlenebildiği ölçüde özünde bireyin, genelinde toplumun dinamiklerinin daha rahat anlaş1labileceği düşünülmektedir. Yaşamın ve insana dair her şeyin üzerinde egemen olması nedeniyle şiddetin bu çözümlemesi, modern Amerikan bireyinin de yaşam alanını anlamaya yardımcı olacaktır. Tüm bu çözümlemenin modern Amerikan tiyatrosu üzerinden yapılması ise tiyatronun özellikle modern Amerikan halkı için diğer edebi türlere göre daha popüler ve yaygın olmasındandır. Diğer edebi türlerden açık oranda daha yoğun bir şekilde şiddet, sahnede resmedilmiş, yazarları tarafından eleştirilmiş ve şiddetin modern birey üzerindeki baskısı halka doğrudan aynı ortam paylaştırılarak ve özdeşlik kurularak daha rahat bir şekilde verilebilmiştir. Daha iyi olanakları olduğu için (görsellik, yardımc1 unsurlar vb.) şiddetin somutlaştırılması da buna paralel olarak daha kolay olmuştur; bu yüzden şiddetin temsili Amerikan tiyatrosunda tematik bağlamda önemlidir. Halka, karşılaştığ 1 ve yaşadığ1 psikolojik, ekonomik ve kültürel sorunları sahnede daha iyi tanıma firsatı verir. Şiddetin Amerikan kültüründeki etkisi ise tüm Amerikan tiyatro geleneği içerisinde sahneye sufle edilerek oyunların arka planlarını oluşturmuştur.

\section{Kaynakça}

Brockett, Oscar. Tiyatro Tarihi. Haz., İnönü Bayramoğlu. Ankara: Dost Kitabevi Yay., 2000.

Strong, Josiah. Our Country: Its Possible Future and Its Present Crisis. USA: The Classics US, 2013.

Tiyatro-terimleri. “Tiyatro Terimleri Sözlüğ̈̈”. Son güncelleme 3 Ağustos, 2013. http://tiyatro-terimleri.bunedir.org/undefined?

Wadsworth Publishing. A People \& A Nation. United States: Wadsworth Publishing, 2014.

Wikipedia. "Broadway". Son güncelleme 13 Haziran, 2019. https://tr.wikipedia.org/wiki?$\underline{\text { curid }=1092779}$ 